\title{
EVALUASI SEGREGASI QUANTITATIVE TRAIT LOCI (QTL) PADA TANAMAN PADI SAWAH VARIETAS LOKAL YANG DIGOGOORGANIKKAN
}

\author{
Zelwia Tiasmitha Astorhie, Saiful Hikam \& Paul B Timotiwu \\ Jurusan Agroteknologi, Fakultas Pertanian Universitas Lampung, \\ Jl.Prof. Soemantri Brodjonegoro, No.1, Bandar Lampung 35145 \\ E-mail: zelwiatm@yahoo.co.id
}

\begin{abstract}
ABSTRAK
Penelitian bertujuan untuk (1) mendapatkan entri (varietas-QTL) yang dapat bertahan di lingkungan gogo sehingga dapat direkomendasi sebagai tetua dalam perakitan padi hibrida; (2) mendapatkan entri yang memiliki ragam genetik dan heritabilitas broad-sense pada padi varietas lokal yang digogoorganikkan; dan (3) mendapat peubah yang dapat dijadikan seleksi tidak langsung yang berpengaruh terhadap seleksi langsung (produksi). Penelitian dilaksanakan pada bulan Desember 2012-April 2013 di Politeknik Negeri Lampung dan Laboratorium Benih, Fakultas Pertanian, Universitas Lampung.Rancangan perlakuan disusun berdasarkan kuasi RTS (Rancangan Teracak Sempurna) karena dalam penelitian ini tidak memungkinkan untuk dilakukan pengulangan kelompok sehingga, ulangan berada di dalam kelompok.Masing-masing kelompok diambil 9 sampel tanaman yang dibagi menjadi 3 ulangan, dan setiap ulangan terdiri dari 3 tanaman. Sebelum dianalisis ragam, rerata pengamatn masingmasing variabel diuji Bartlett dan Levene untuk kehomogenan ragam. Bila hasil analisis ragam nyata pada $\mathrm{P} \leq 0,01$ atau 0,05 maka, dilakukan pemeringkatan nilai tengah dengan Beda Nyata Jujur (BNJ). Seluruh statistika data menggunakan software Statistic Analysis System (SAS) 9.1 for Windows.Besarnya ragam genetik dan heritabilitas broad-sense diduga berdasarkan kuadrat nilai tengah harapan pada hasil analisis ragam. Hasil penelitian menunjukkan bahwa: (1) PB Bogor-tinggi tanaman $\left(801,50 \mathrm{~g} / \mathrm{m}^{2}\right)$ Kesit-tinggi tanaman $\left(546,77 \mathrm{~g} / \mathrm{m}^{2}\right)$ dan Tewe-jumlah anakan $\left(487,57 \mathrm{~g} / \mathrm{m}^{2}\right)$ mampu bertahan di lingkungan gogoorganik sehingga, dapat direkomendasi sebagai tetua dalam perakitan padi hibrida; (2) semua peubah yang diamati mampu memberikan perbedaan ragam genetik dan heritabilitas broad-sense; dan (3) karakter jumlah anakan total dapat dijadikan seleksi tidak langsung yang dapat meningkatkan hasil produksi.
\end{abstract}

Kata kunci: gogo organik, heritabilitas broad-sense, padi, quantitative trait loci (qtl), ragam genetik, seleksi tidak langsung, varietas padi lokal.

\section{PENDAHULUAN}

Penduduk Indonesia dari tahun ke tahun semakin bertambah, dengan pertumbuhan sekitar 1,6\% tahun ${ }^{-1}$, sehingga mendorong pemintaan pangan yang terus meningkat. Sementara lahan pertanian khususnya lahan sawah pada saat ini ternyata belum mampu memenuhi kebutuhan pangan Indonesia.

Kebutuhan beras yang terus meningkat menuntut peningkatan produktivitas padi dengan segera.Upaya pemerintah untuk meningkatan produksi yaitu dengan cara ekstensifikasi pertanian, yang memanfaatkan lahan kering dengan menanam padi gogo. Namun menurut De Datta dan Vergara (1975 dalam Perwira, 2004) pada kenyataannya penanaman padi gogo banyak mengalami hambatan, karena padi gogo banyak dibudidayakan pada lahan tadah hujan maka air menjadi salah satu unsur yang mempengaruhi pertumbuhannya.

Untuk membantu memperbaiki kondisi lahan kering dilakukan penambahan bahan organik. Menurut Supartha (2012) pupuk organik merupakan hasil dekomposisi bahan-bahan organik yang diuraikan oleh mikroba, yang hasil akhirnya dapat menyediakan unsur hara yang dibutuhkan tanaman untuk pertumbuhan dan perkembangan tanaman.

Selain pemanfaatan lahan kering dan penggunaan bahan organik, peningkatan produksi padi dapat pula dengan mengembangkan varietas unggul. Salah satunya yaitu dengan penggunaan padi hibrida dan inbrida. Padi hibridamempunyai potensi hasil lebih tinggi dibandingkan dengan varietas padi inbrida. Padi lokal (land race) merupakan salah satu plasma nutfahyang potensial sebagai sumber gen yang mengendalikan sifat penting pada tanaman. Keragaman genetik yang tinggi pada padi lokal ini yang dimanfaatkan dalam program pemuliaan padi dalam perbaikan tetua padi secara umum (Hairmansis dkk., 2005).Usaha untuk meningkatkan produksi padi dengan hibrida sangat sulit dilakukan, karena kelemahan hibrida tidak dapat diturunkan menjadi benih, sehingga petani harus membeli benih setiap musim tanam.

Untuk itu dilakukan salah satu alternatif untuk meningkatkan produksi padi yaitu dengan analisis QTL (quantitative trait loci). QTL disini berperan dalam 
mengendalikan sifat/karakter suatu gen yang dimiliki tanaman, kemudian sifat tersebut harus dideteksi terlebih dahulu. QTL juga dilakukan untuk mendeteksi sifat tinggi tanaman, jumlah anakan, dan jumlah gabah yang ditanam di lingkungan gogoorganik. Penelitian ini sebelumnya dilakukan di ketiga lokasi yang berbeda yaitu, sawah tadah hujan (Tulang Bawang Barat), sawah irigasi (Way Jepara), dan sawah baru (Polinela I). Pemindahan lingkungan abiotik ini membuat tanaman harus melakukan adaptasi yang sangat mungkin akan mengalami segregasi fenotipe karena sebelumnya ditanam di tiga lokasi yang berbeda.

\section{BAHAN DAN METODE}

Penelitian dilaksanakan pada bulan Desember 2012 - April 2013 di Politeknik Negeri Lampung dan Laboratorium Benih Fakultas Pertanian, Universitas Lampung.Bahan yang digunakan dalam penelitian ini adalah pupuk organik (kotoran sapi) dan empat varietas padi, yaitu Gendut, PB Bogor, Kesit, dan Tewe. Alat yang digunakan adalah bendera sampel, kantung plastik, gunting, cutter, penggaris, pensil, timbangan, seed blower, seed counter, oven, kamera digital, kertas, dan paranet. Dalam Penelitian ini disusun berdasarkan kuasi RTS (Rancangan Teracak Sempurna) karena dalam penelitian ini tidak menggunakan ulangan kelompok namun ulangan berada di dalam kelompok dengan 3 ulangan untuk setiap sampel. Sebelum dianalisis ragam, rerata pengamatan pada masing-masing variabel diuji Bartlett dan Levene untuk kehomogenan ragam.Bila hasil analisis ragam nyata pada $\mathrm{P} \leq 0,01$ atau 0,05 maka dilakukan pemeringkatan nilai tengah dengan uji Beda Nyata Jujur (BNJ). Besar ragam genetik dan heritabilitas broad-sense juga diduga berdasarkan nilai kuadrat nilai tengah harapan pada hasil analisis ragam dan rancangan percobaan yang digunakan sesuai dengan model matematika berdasarkan Hallauer dan Miranda (1986 dalam Hikam, 2010).

Lahan terlebih dahulu diolah dengan menggunakan bajak. Kemudian dibuat bedengan untuk tiap varietas seluas $2 \times 1 \mathrm{~m}$. Setelah lahan siap, penanaman benih dilakukan dengan cara tabela (tanam benih langsung) dengan jarak $25 \times 25 \mathrm{~cm}$, yang setiap masing-masing lubang diberi 2 benih. Pemupukan dilakukan sebanyak 2 kali, pertama pada saat pengolahan tanah dan yang kedua saat tanaman berumur 3 MST. Pupuk kandang yang digunakan adalah pupuk kandang sapi dengan masing-masing dosis $5 \mathrm{t} \mathrm{ha}^{-1}$. Pengendalian hama dan penyakit serta gulma, dilakukan dengan cara manual. Lalu, padi yang siap untuk dipanen harus memiliki kriteria 90\% bulir padi telah menguning, serta bulir gabah terasa keras apabila ditekan serta tidak mengeluarkan cairan putih susu lagi.

Variabel yang diamati dalam penelitian ini yaitu tinggi tanaman, jumlah anakan produktif, jumlah anakan non-produktif, jumlah anakan total, jumlah malai, bobot kering malai, jumlah benih per malai, jumlah gabah isi, bobot gabah isi, jumlah gabah hampa, bobot gabah hampa, jumlah gabah total, bobot gabah total, bobot 100 biji, dan produksi per $\mathrm{m}^{2}$.

\section{HASIL DAN PEMBAHASAN}

Nilai kuadrat nilai tengah dan hasil evaluasi karakter vegetatif disajikan pada Tabel 1 . Kedua karakter vegetatif menunjukkan berbeda nyata.Perbedaan tersebut sangat mungkin terjadi karena secara genotipe dan fenotipe entri yang digunakan memiliki varietas dan QTL berbeda-beda. Nilai koefisien keragaman (KK)pada kedua karakter vegetatif tersebut sebesar 3,92 dan 15,68 . Nilai KK yang $<25,6 \%$ tanaman tersebut lebih banyak dipengaruh faktor genetik dan faktor lingkungan sangat kecil. Sedangkan, nilai

Tabel 1.Rekapitulasi kuadrat nilai tengah pada Entri untuk peubah vegetatif

\begin{tabular}{cccc}
\hline Sumber keragaman & DK & Tinggi tanaman & Jumlah anakan total \\
\hline Entri & 10 & $154,52^{* *}$ & $21,65^{*}$ \\
Galat & 22 & 10,39 & 6,95 \\
Total & 32 & & \\
KK $(\%)$ & & 3,92 & 15,68 \\
Xbar & & 82,30 & 16,82 \\
Stdev & 7,40 & 3,39 \\
Max & & 93,33 & 23,33 \\
Min & & 69,67 & 10,00 \\
\hline
\end{tabular}

Keterangan: * dan $* *$ berbeda pada $\mathrm{P} \leq 0,01$ dan $\mathrm{P} \leq 0,005$. 
koefisien keragaman >25,6 \% (populasi homogen), sehingga seleksi menggunakan persilangan antarkultivar yang ada di dalam populasi tidak akan menghasilkan peningkatan yang berarti (Hallauer dan Miranda, 1981 dalam Saputri, 2012).

Hal tersebut juga sejalan dengan penelitian sebelumnya (Suprayogi, 2011; Suwantike, 2011; dan Ramadhana, 2012) yang menunjukkan nilai KK pada karakter tinggi tanaman dan jumlah anakan total < $25,6 \%$. Sehingga, kedua karakter vegetatif tetap dapat konsisten, dan karakter tersebut dapat dijadikan seleksi dalam program pemuliaan tanaman.

Kuadrat nilai tengah dan hasil evaluasi karakter generatif disajikan pada Tabel 2. Dari keseluruhan karakter generatif menunjukkan perbedaan antar tanaman yang diamati. Walaupun sebagian karakter generatif memiliki $\mathrm{KK}<25,6 \%$, namun pada karakter lainnya dapat dilakukan seleksi lebih lebih ketat lagi untuk mendapatkan karakter yang dapat meningkatkan hasil produksi.

Peringkat entri berdasarkan $\mathrm{BNJ}_{0.05}$ disajikan pada Tabel 3. Pada tabel tersebut terlihat bahwa respon yang ditunjukkan pada setiap tanaman sama, namun fenotipe yang muncul pada karakter berbeda-beda. Pada karakter jumlah anakan produktif yang tertinggi dimiliki oleh Tewe-jumlah gabah namun tidak sesuai dengan produksi yang dihasilkan. Sementara untuk produksi tertinggi dimiliki oleh PB Bogor-tinggi tanaman.Hal tersebut dikarenakan keseluruhan dari jumlah gabah total yang dimilki Tewe-jumlah gabah sebagian besar hampa, yang diduga karena QTL yang berperan mengendalikan sifat baik pada tanaman padi tidak terekspresi pada saat ditanam di lingkungan gogo organik, atau tanaman tersebut tidak tahan pada lingkungan kering.

Selain PB Bogor-tinggi tanaman, untuk Kesittinggi tanaman dan Tewe-jumlah anakan memilki jumlah produksi yang cukup tinggi yaitu, bekisar $487-546 \mathrm{~g} / \mathrm{m}^{2}$ (Tabel 3) yang apabila dikonversikan bekisar 4-5 $\mathrm{t} \mathrm{ha}^{-1}$. Melihat jumlah tersebut untuk varietas lokal yang ditanam di lingkungan darat organik sangat cukup baik.Sehingga, selain PB Bogor-tinggi tanaman, untuk Kesit-tinggi tanaman dan Tewe-jumlah anakan dapat juga direkomendasikan sebagai entri yang dapat digunakan sebagai tetua untuk perakitan padi hibrida.

Pendugaan nilai dugaan ragam genetik, koefisien keragaman genetik, dan heritabilitas disajikan pada Tabel 4.Untuk keberhasilan program pemuliaan sangat ditentukan oleh tersedianya ragam genetik. Setiap karakter akan mempunyai kriteria rentang keragaman yang berbeda. Kriteria keragaman diabsolutkan terhadap nilai keragaman yang tertinggi.Tabel 4 menunjukkan bahwa keragaman genetik yang dimiliki hanya sebagaian

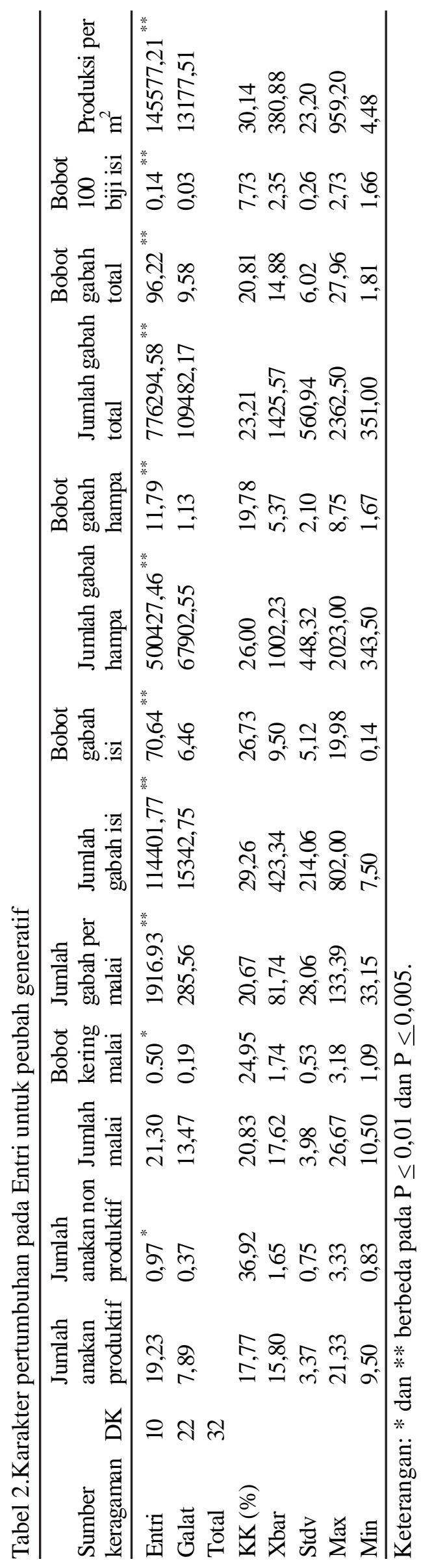


Tabel 3.Peringkat Entri berdasarkan $\mathrm{BNJ}_{0.05}$

\begin{tabular}{|c|c|c|c|c|c|c|c|c|c|c|c|c|c|c|c|c|c|}
\hline Entri & $\begin{array}{l}\text { Tinggi } \\
\text { tanaman }\end{array}$ & $\begin{array}{c}\text { Jumlah } \\
\text { anakan } \\
\text { produktif }\end{array}$ & $\begin{array}{c}\text { Jumlah } \\
\text { anakan non } \\
\text { produktif }\end{array}$ & $\begin{array}{c}\text { Jumlah } \\
\text { anakan } \\
\text { total }\end{array}$ & $\begin{array}{c}\text { Jumlah } \\
\text { malai }\end{array}$ & $\begin{array}{l}\text { Bobot } \\
\text { kering } \\
\text { malai }\end{array}$ & $\begin{array}{l}\text { Jumlah } \\
\text { gabah per } \\
\text { malai }\end{array}$ & $\begin{array}{l}\text { Jumlah } \\
\text { gabah } \\
\text { isi }\end{array}$ & $\begin{array}{l}\text { Bobot } \\
\text { gabah } \\
\text { isi }\end{array}$ & $\begin{array}{l}\text { Jumlah } \\
\text { gabah } \\
\text { hampa }\end{array}$ & $\begin{array}{l}\text { Bobot } \\
\text { gabah } \\
\text { hampa }\end{array}$ & $\begin{array}{l}\text { Jumlah } \\
\text { gabah } \\
\text { total }\end{array}$ & $\begin{array}{l}\text { Bobot } \\
\text { gabah } \\
\text { total }\end{array}$ & $\begin{array}{l}\text { Bobot } \\
100 \\
\text { biji isi }\end{array}$ & $\begin{array}{l}\text { Produksi } \\
\text { per } \mathrm{m}^{2}\end{array}$ & $\begin{array}{l}\text { Jumlah } \\
\text { huruf a }\end{array}$ & $\begin{array}{l}\text { Pering- } \\
\text { kat }\end{array}$ \\
\hline Gendut-Tt & $92,17 \mathrm{a}$ & $13,06 \mathrm{a}$ & 2,25 & $14,89 \mathrm{a}$ & $13,89 \mathrm{a}$ & $1,35 \mathrm{a}$ & $91,47 \mathrm{a}$ & $438,60 \mathrm{a}$ & 8,81 & $855,40 \mathrm{a}$ & $4,23 \mathrm{a}$ & $1294,00 \mathrm{a}$ & 13,04 & $2,29 \mathrm{a}$ & 388,48 & 11 & 2 \\
\hline Gendut- Ja & 78,22 & $14,67 \mathrm{a}$ & 1,39 & $15,22 \mathrm{a}$ & $17,00 \mathrm{a}$ & $1,80 \mathrm{a}$ & 76,99 a & $378,30 \mathrm{a}$ & 7,59 & $900,80 \mathrm{a}$ & $3,59 \mathrm{a}$ & $1279,10 \mathrm{a}$ & 11,17 & 2,09 & 364,16 & 9 & 3 \\
\hline Gendut- Jg & 78,17 & $12,00 \mathrm{a}$ & 1,08 & 12,17 & $14,17 \mathrm{a}$ & $1,67 \mathrm{a}$ & 41,57 & 21,20 & 0,42 & $613,70 \mathrm{a}$ & $3,01 \mathrm{a}$ & 634,80 & 3,43 & 1,96 & 9,87 & 6 & 4 \\
\hline Kesit- Tt & 73,11 & $17,33 \mathrm{a}$ & 2,61 & $19,55 \mathrm{a}$ & $17,89 \mathrm{a}$ & $1,36 \mathrm{a}$ & 63,32 & $506,20 \mathrm{a}$ & $11,39 \mathrm{a}$ & $560,00 \mathrm{a}$ & $3,46 \mathrm{a}$ & 1066,20 & $14,85 \mathrm{a}$ & $2,44 \mathrm{a}$ & $546,77 \mathrm{a}$ & 11 & 2 \\
\hline Kesit- Jg & 73,22 & $18,56 \mathrm{a}$ & 1,67 & $19,67 \mathrm{a}$ & $19,67 \mathrm{a}$ & 1,33 & 49,27 & 269,10 & 6,35 & $692,20 \mathrm{a}$ & 8,41 & 961,30 & $14,77 \mathrm{a}$ & $2,45 \mathrm{a}$ & 304,91 & 6 & 4 \\
\hline $\mathrm{Pb}$ Bogor- $\mathrm{Tt}$ & $91,78 \mathrm{a}$ & $15,89 \mathrm{a}$ & 2,17 & $17,56 \mathrm{a}$ & $17,00 \mathrm{a}$ & $2,07 \mathrm{a}$ & $103,04 a$ & $645,40 a$ & $16,70 \mathrm{a}$ & 1112,40 & 6,31 & $1757,90 \mathrm{a}$ & $23,01 \mathrm{a}$ & $2,68 \mathrm{a}$ & $801,55 \mathrm{a}$ & 12 & 1 \\
\hline Pb Bogor-Ja & $86,00 \mathrm{a}$ & $14,00 \mathrm{a}$ & 1,50 & $15,00 \mathrm{a}$ & $16,67 \mathrm{a}$ & $1,60 \mathrm{a}$ & $100,31 a$ & $668,70 \mathrm{a}$ & $15,45 \mathrm{a}$ & $1007,30 \mathrm{a}$ & 5,58 & $1676,00 \mathrm{a}$ & $21,03 \mathrm{a}$ & $2,53 \mathrm{a}$ & 247,20 & 12 & 1 \\
\hline Tewe- Ja & $85,56 \mathrm{a}$ & $17,33 \mathrm{a}$ & 1,00 & $17,33 \mathrm{a}$ & $20,78 \mathrm{a}$ & $1,87 \mathrm{a}$ & $97,08 \mathrm{a}$ & $452,60 \mathrm{a}$ & $10,16 \mathrm{a}$ & 1503,90 & 5,65 & $1956,40 \mathrm{a}$ & $15,80 \mathrm{a}$ & $2,32 \mathrm{a}$ & $487,57 \mathrm{a}$ & 11 & 2 \\
\hline Tewe- Jg & 82,50 & $19,33 \mathrm{a}$ & 1,19 & $20,00 \mathrm{a}$ & $21,50 \mathrm{a}$ & $2,58 \mathrm{a}$ & $112,61 \mathrm{a}$ & $430,00 \mathrm{a}$ & 8,67 & 1774,30 & 8,11 & $2204,30 a$ & $16,77 \mathrm{a}$ & $2,38 \mathrm{a}$ & 277,39 & 9 & 3 \\
\hline BNJ & 9,22 & 8,03 & 1,74 & 7,54 & 10,50 & 1,24 & 48,35 & 354,37 & 7,23 & 745,49 & 3,04 & 946,61 & 8.86 & 0,52 & 328,41 & & \\
\hline Standar komersial & $107-115$ & $14-15$ & & & & & \pm 90 & & & & & & & 2,80 & 600,00 & & \\
\hline
\end{tabular}

Keterangan: $\mathrm{Tt}=$ tinggi tanaman, Ja = jumlah anakan, Jg = jumlah gabah. Standar komersial yang digunakan adalah Varietas Ciherang.

Tabel 4. Nilai dugaan ragam genetik, heritabilitas broad-sense, dan koefisien keragaman genetikuntuk karakter vegetatif dan generatif

\begin{tabular}{lccc}
\hline Variabel & \multicolumn{1}{c}{$\sigma^{2} \mathrm{~g} \pm \mathrm{GB} \sigma^{2} \mathrm{~g}$} & $\mathrm{~h}_{B S}^{2} \pm \mathrm{GB} \mathrm{h}^{2}{ }_{B S}(\%)$ & $\mathrm{KKg}(\%)$ \\
\hline Tinggi tanaman & $48,04 \pm 23,06^{* *}$ & $93,28 \pm 44,77^{* *}$ & 8,42 \\
Jumlah anakan produktif & $3,78 \pm 2,98^{*}$ & $58,94 \pm 46,57^{*}$ & 12,30 \\
Jumlah anakan non produktif & $0,20 \pm 0,15^{*}$ & $61,74 \pm 46,33^{*}$ & 27,08 \\
Jumlah anakan total & $4,90 \pm 3,31^{*}$ & $67,88 \pm 45,86^{*}$ & 13,16 \\
Jumlah malai & $2,61 \pm 3,48^{*}$ & $36,80 \pm 48,99^{*}$ & 9,17 \\
Bobot kering malai & $0,10 \pm 0,08^{*}$ & $62,33 \pm 46,28^{*}$ & 18,52 \\
Jumlah gabah per malai & $543,79 \pm 287,34^{*}$ & $85,10 \pm 44,97^{*}$ & 28,53 \\
Jumlah gabah isi & $33019,67 \pm 17130,52^{*}$ & $86,59 \pm 44,92^{* *}$ & 42,92 \\
Bobot gabah isi & $21,39 \pm 10,55^{* *}$ & $90,85 \pm 44,81^{* *}$ & 48,66 \\
Jumlah gabah hampa & $144175,00 \pm 74941,91^{*}$ & $86,43 \pm 44,93^{* *}$ & 37,88 \\
Bobot gabah hampa & $3,55 \pm 1,76^{* *}$ & $90,04 \pm 44,83^{* *}$ & 35,09 \\
Jumlah gabah total & $22270,80 \pm 116297,20^{*}$ & $85,90 \pm 44,93^{* *}$ & 33,07 \\
Bobot gabah total & $28,88 \pm 14,38^{* *}$ & $90,04 \pm 44,83^{* *}$ & 36,13 \\
Bobot 100 biji & $0,04 \pm 0,02^{* *}$ & $77,09 \pm 45,30^{*}$ & 8,19 \\
Produksi per m ${ }^{2}$ & $44133,23 \pm 21745,78^{* *}$ & $90,95 \pm 44,81^{* *}$ & 55,16 \\
\hline
\end{tabular}

Keterangan: $\mathrm{H}_{B S}=$ Heritabilitas broad-sense, $*$ = berbeda dari nol $\left(\mathrm{o}^{2} \mathrm{~g}\right.$ atau $\left.\mathrm{h}^{2}{ }_{B S} \geq 1 \mathrm{~GB}\right), * *=$ berbeda dari nol $\left(\mathrm{o}^{2} \mathrm{~g}\right.$ atau $\left.\mathrm{h}^{2}{ }_{B S} \geq 2 \mathrm{~GB}\right), \mathrm{GB}=$ galat baku, dan $\mathrm{KKg}=$ koefisien keragaman genetik. 
yang tinggi karena $\geq 2$ GBó $^{2}$ g yaitu karakter tinggi tanaman, bobot gabah isi, bobot gabah total, bobot 100 biji, dan produksi per $\mathrm{m}^{2}$.Sehingga dapat diduga genetik lebih berperan.Hal ini menunjukkan bahwa meskipun karakter tersebut dipengaruhi oleh faktor lingkungan, namun peran faktor genetik cukup besar. Stanfield (1991 dalam Jambormias, 2007) menyatakan bahwa tingginya ragam genetik berimplikasi pada tingginya nilai heritabilitas arti luas.

Nilai heritabilitas merupakan nilai duga pewarisan sifat yang diturunkan ke zuriatnya.Hasil penelitian ini memiliki nilai heritabilitas atau daya waris yang tinggi.Besarnya nilai peluang suatu sifat yang diturunkan dari tetua kepada turunannya dapat dilihat dari nilai $\mathrm{h}_{B S^{*}}$ Kriteria tanaman yang memiliki heritabilitas tinggi apabila $\mathrm{h}_{B S}^{2}>50$, sedang bekisar $20<\mathrm{h}_{B S}^{2}<50$, dan rendah berkisar $\mathrm{h}^{2}{ }_{B S}<20$.

Keragaman genetik di dalam populasi terhadap karakterpertumbuhan tanaman dapat dihitung dengan menggunakan nilai KKg tiap parameter tersebut. Menurut Jamilah (2011), menyatakan bahwa keragaman genetik yang tinggi akan memberikan kesempatan yang luas untuk melakukan seleksi, namun jika keragaman genetik rendah maka seleksi harus dilakukan secara ketat agar diperoleh genotipe yang diinginkan pada karakter tertentu. Hallauer dan Miranda (1986 dalam Suprayogi, 2011) menyatakan nilai KKg yang baik pada kondisi ideal bekisar antara 5-10\%. Nilai KKg $\leq 10 \%$ dianggap takbias yang berarti terpakainya kinerja fenotipe sebagai penduga genotipe dengan lingkungan tidak dapat diabaikan.

Korelasi merupakan keeratan hubungan antara dua karakter yang berbeda. Informasi tentang adanya korelasi merupakan hal yang terpenting dalam pemuliaan tanaman.Tabel 5 menunjukkan terdapat korelasi positif nyata antara karakter bobot gabah isi terhadap karakter tinggi tanaman, jumlah anakan, jumlah gabah per malai, jumlah serta bobot gabah total, bobot 100 biji isi, dan produksi per $\mathrm{m}^{2}$. Karakter yang memiliki nilai korelasi positif terhadap produksi selain bobot gabah isi juga dimiliki oleh jumlah gabah per malai, jumlah gabah isi, bobot gabah isi, jumlah gabah total, dan bobot gabah total.

Seleksi merupakan langkah awal bagi pemuliaan tanaman dalam merakit suatu varietas dan merupakan dasar dari seluruh perbaikan tanaman untuk mendapatkan varietas unggul baru.Seleksi tidak langsung merupakan pemilihan secara tidak langsung yang berhubungan dengan hasil produksi yang bertujuan untuk mendapatkan individu-indiviu yang memiliki karakter tertentu yang diharapkan.

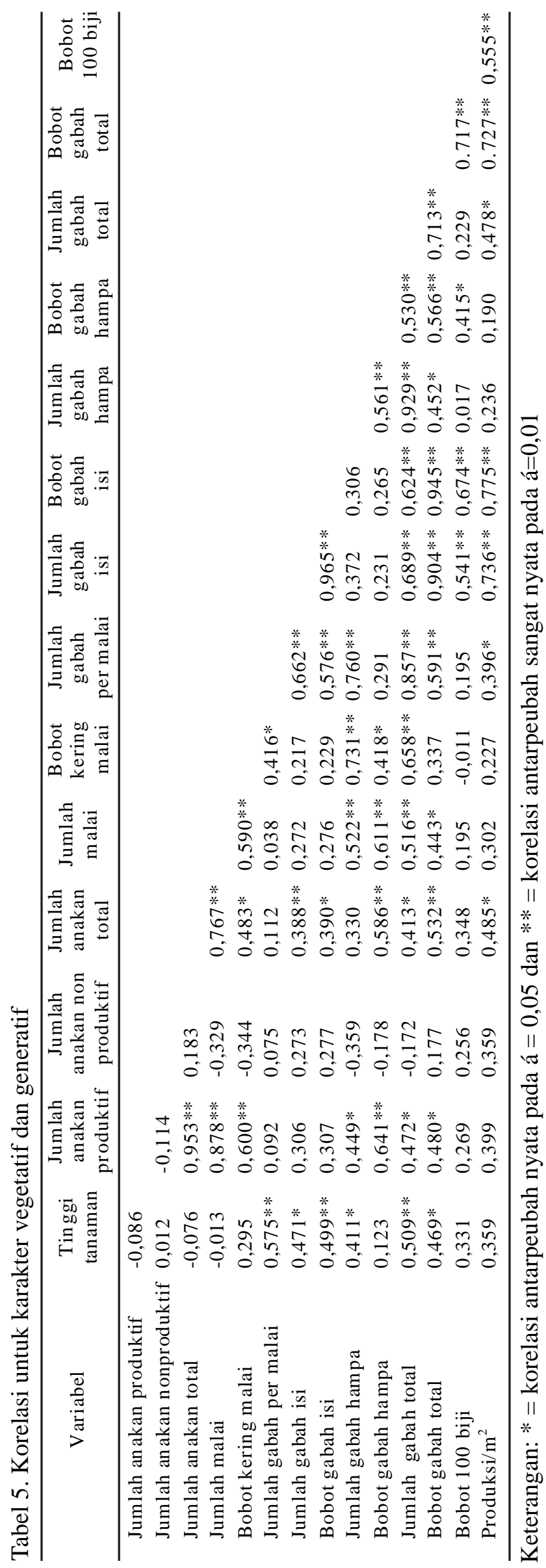


Agar peubah sesuai untuk dijadikan seleksi tidak langsung maka harus memenuhi kriteria sebagai berikut yaitu, (1) memiliki korelasi positif dengan produktifitas; (2) mempunya nilai ó ${ }^{2} \mathrm{~g}$ dan $\mathrm{h}^{2}{ }_{B S}$ yang $>$ GB masingmasing; (3) mudah diukur dengan alat ukur yang sederhana atau tersedia; dan (4) dapat diukur pada saat vegetatif dan tidak perlu menunggu sampai panen (Hikam dan Yuliadi, 1996 dalam Ramadhana 2013), dan (5) logis. Sehingga tidak hanya nilai korelasi yang positif dengan hasil yang dapat dijadikan salah satu kriteria seleksi.Karakter yang dapat dijadikan indikator seleksi tidak langsung adalah yang memiliki hubungan dengan karakter yang menunjang ke produksi. Pada penelitian ini dipilih jumlah anakan total (Gambar 1) karena karakter tersebut memenuhi kriteria.

\section{KESIMPULAN}

Dari penelitian ini disimpulkan bahwa (1) PB Bogor-tinggi tanaman $\left(801,50 \mathrm{~g} / \mathrm{m}^{2}\right)$ Kesit-tinggi tanaman $\left(546,77 \mathrm{~g} / \mathrm{m}^{2}\right)$ dan Tewe-jumlah anakan $(487,57$ $\mathrm{g} / \mathrm{m}^{2}$ ) mampu bertahan di lingkungan gogoorganik sehingga, dapat dijadikan rekomendasi sebagai tetua dalam perakitan padi hibrida; (2) semua peubah yang diamati mampu memberikan perbedaan ragam genetik dan heritabilitas broad-sense; dan(3) karakter untuk jumlah anakan total dapat dijadikan seleksi tidak langsung yang dapat meningkatkan hasil produksi.

\section{SANWACANA}

Ucapan terimakasih penulis sampaikan kepada Lembaga IM HERE dan Ir. Denny Sudrajad, M.P.

\section{PUSTAKA ACUAN}

Hairmansis, A., Aswidinnoor, Trikoesoemaningtyas, dan Suwarno. 2005. Evaluasi daya pemulihan kesuburan padi lokal dari kelompok tropikal japonica. Bul.Agron. 33(3):1-6.

Jambormias, E., Surjono, H.S., Muhammad, J., dan Suharsono. 2007. Keragaan dan keragamaan genetik sifat-sifat kuantitatif kedelai (Glycine max L. Merril) pada generasi seleksi F6 persilangan varietas slamet $\mathrm{x}$ nokhonsawan. Bul. Agron. 35(3):168-175

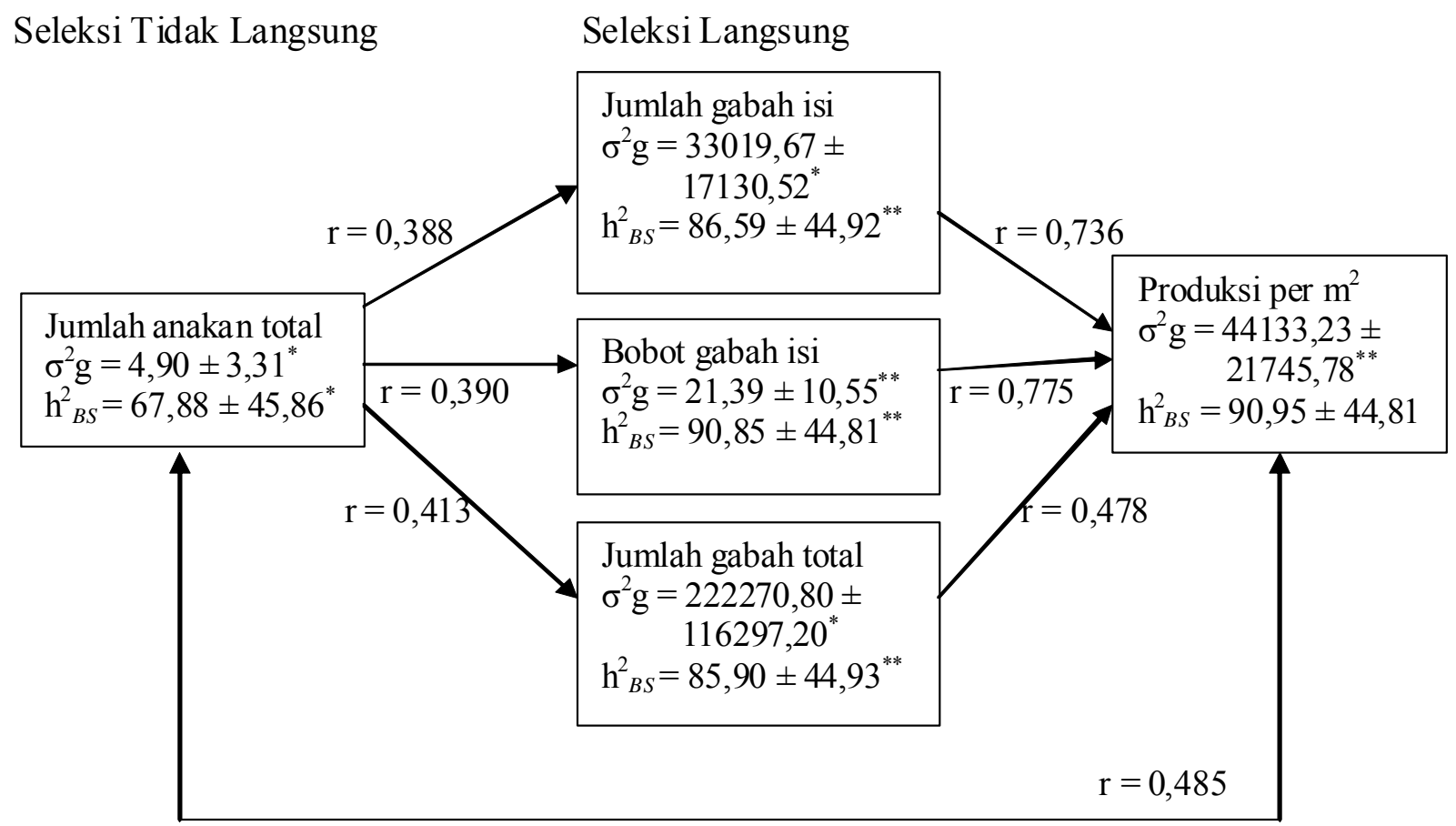

Gambar 1. Penetapan peubah untuk seleksi tidak langsung yang berpengaruh terhadap seleksi langsung produksi) menggunakan nilai $\mathrm{o}^{2} \mathrm{~g}, \mathrm{~h}^{2}{ }_{B S}$, dan $\mathrm{r}$ varietas yang memenuhi persyaratan : $\mathrm{r}=* / * * ; \dot{o}^{2} \mathrm{~g}=* / * * ; \operatorname{dan}^{2}{ }_{B S}=* /$ $* *$. 
Jamilah, C., Budi W., dan Agung K. 2011. Parameter genetik aksesi tanaman kerabat liar ubi jalar koleksi unpad untuk peningkatan genetik dan sumber perbaikan karakter ubi jalar. Makalah Seminar Nasional Pemuliaan Berbasis Potensi dan Kearifan Lokal Menghadapi Tantangan Globalisasi.

Perwira, A.D. 2004. Keragaan karakter agronomi generasi F3 enam persilangan padi Gogo. Skripsi. Institut Pertanian Bogor.

Ramadhana, R. 2013. Evaluasi fenotipe quantitaive trait loci (QTL) yang tersegregasi transgresif pada varietas padi nasional dan lokal di lingkungan sawah baru. Skripsi. Universitas Lampung.
Saputri Y.S. 2012. Pendugaan komponen genetik, daya gabung, dan segregasi biji pada jagung manis kuning kisut. Jurnal Agrotek 1(1): 25-31.

Supartha, I.N.Y., Gede, W., dan Gede, M.A. 2012. Aplikasi jenis pupuk organik pada tanaman padi sistem pertanian organik. E-Jurnal Agroekoteknologi Tropika 1(2):98-106.

Suprayogi, L. 2011. Evaluasi plasma nutfah padi yang tersegregasi transgresif sebagai tetua inbred pada perakitan padi inbrida dan hibrida. Skripsi. Universitas Lampung.

Suwantike, I.K.T. 2011. Evaluasi fenotipe QTL 6 varietas padi tersegregasi transgresif untuk koleksi plasma nutfah pada perakitan padi inbrida. Skripsi. Universitas Lampung. 